\title{
ANIMAL-STORIES FROM CALABAR
}

\author{
Contributed by Hexry Conkns, Native Arristent Inspector of Police, \\ Sonth Nigeria Police Farce.
}

The Tortoise, Elephant and Hippopotamus

ONCE upon a time Tortoise, Elephant and Hippopotamus were great friends. One day, as the Tortoise was walking with the Elephant, he told him that although he himself was so small compared with the Elephant, yet he could pull the latter right into a river. When the Elephant heard this, he laughed him to scorn and told him that was impossible. The Tortoise having obtained his permission, tied a rope round the Elephant's body, and told him to stand where he was. He himself then walked to a river with the other end of the rope in his hand. When he got to the river he greeted his friend the Hippopotamus, saying he could pull him out of the river. The Hippopotamus also laughed at him most sarcastically, and at once told him to try it. Tortoise therefore passed the rope round the body of the Hippopotamus and told him to plunge into the river and to start pulling at once. The Hippopotamus jumped into the water accordingly and began to pull in earnest. At the same time the Elephant began to pull very furiously until both were quite tired. Tired and exceedingly surprised, they walked slowly towards each other to see whether it really was the Tortoise that was pulling them. When they found that it was they themselves who were pulling one another, they were very angry and swore that they would kill the Tortoise wherever they saw him.

\section{Tortoise's Creditors}

Once upon a time there was a famine in the land. The tortoise therefore went to his friends, the worm, cock, wild 
cat, leopard and a hunter and borrowed from each of them seven boxes of [brass] rods, which he promised to pay at the end of the season on different days. At the appointed time the worm went to him for payment. The tortoise told him to wait while he went to fetch the money. On the next day he came back followed by the cock, who seeing the worm went on him at once and swallowed him up. After this the cock told him that he came for his debt. He told the cock also to wait while he went to get the money. On his return he was accompanied by the wild cat, who jumped on the cock as soon as he saw him and immediately devoured him. When the cat had finished he informed the tortoise that he had come for his debt. The tortoise asked him also to wait until he went and got the money; and on his return he was followed by the leopard, who attacked the wild cat immediately and killed him. The leopard then informed him of the cause of his visit and was asked to wait a little, while he went out to get the money. Shortly afterwards he came back accompanied by the hunter, who fired at the leopard as soon as he saw him, whereupon the leopard attacked him and both were killed. The tortoise then made use of their corpses and laughed at them as being fools. Hence we should not lend our money to any man, as he would be seeking some way of doing us harm in order that we may lose our money.

\section{The Tortoise and the Pig}

There was a great famine, and the tortoise not having anything to eat, climbed up a palm-tree in order to cut some dates. When he reached the top he fell to the ground and his shell was broken into pieces. He remained there until evening, when all the animals were returning home. As they were passing he besought each of them to collect the pieces of his shell for him, but they all refused except the pig. After the pig had gathered them and put him in it he promised the pig some reward on a certain day. When the day came the pig went to him but was told by Mrs. Tortoise, who was grinding something at the time, that her husband had gone out. The pig was very angry and went 
and pushed away the stone on which Mrs. Tortoise was grinding some leaves, not knowing it was the tortoise himself, lying on his back. After he had left and returned the second time, the tortoise told him to go and find his stone, when he would be paid. The pig therefore went out to look for the stone on the ground and has not yet found it. This is why the pig is always grunting on the ground, and why the tortoise's shell is full of patches.

[The first of these stories will be recognised as "Mr. Terrapin shows his Strength" in Uncle Remus, where (neither Elephant nor Hippopotamus being found in Georgia) one end of "Mrs. Meadows's bed-cord " is given to Brer Bar, and the other tied to the root of a tree. A Duala story, almost identical with Mr. Cobham's, is given by Herr Lederbogen, in the Transactions of the Berlin Oriental Seminary. It also occurs in Cunnic Rabbit, recently reviewed in these pages; and there are numerous variants. The Tortoise appears as the personification of unscrupulous cunning in the Nyasaland story of Kamba ni ng'ansi (ng'anai $=$ Yao ligondo $=$ the monitor lizard). - ED.] 